\title{
The Relationship between Iranian English High School Teachers' Reflective Practices, Their Self-Regulation and Teaching Experience
}

\section{Hamzeh Pazhoman}

Urmia University, Urmia, Iran, h.pazhoman@gmail.com

\section{Mehdi Sarkhosh}

Urmia University, Urmia, Iran

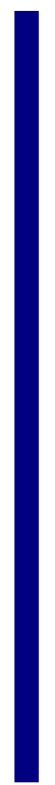

\begin{abstract}
The study examined the relationship between English teachers' reflective practices and their self-regulation. It also explored the relationships between self-regulation and teachers' teaching experiences. To achieve the goal of the study, 103 English teachers from different senior and junior high schools were selected through convenience sampling based on availability and based on their consent to participate in the study. They were asked to complete two questionnaires: the English Language Teaching Reflection Inventory (ELTRI) and the Teacher SelfRegulation Scale (TSRS). The relationship between teachers' reflective practices and their self-regulation was examined by running Spearman correlation coefficient formula. Additionally, the power of reflection and the teachers' experiences in predicting English teachers' self-regulation was investigated by running a multiple regression analysis. The findings revealed a positive relationship between the teachers' reflective practices and their self-regulation. Nevertheless, there were no significant relationships between teachers' selfregulation and their experiences. Reflective practice was also found to be a strong predictor of self-regulation. In light of the results gained, a list of reflective practice techniques for improving English teachers' teaching quality and selfregulation in teacher education were suggested. The results of this study have implications for English language teachers, researchers and teacher trainers in Iran
\end{abstract} and abroad.

Keywords: reflective practices, self-regulation, teaching experience, high school EFL teachers, teacher education

\section{INTRODUCTION}

Reflective practice has been inspired by the works of two pioneering scholars, Dewey (1933) and Schon (1983). When it comes to education, teachers are considered reflective practitioners and instead of only acting according to other experts' views in

Citation: Pazhoman, H. \& Sarkhosh, M. (2019). The Relationship between Iranian English High School Teachers' Reflective Practices, Their Self-Regulation and Teaching Experience. International Journal of Instruction, 12(1), 995-1010. https://doi.org/10.29333/iji.2019.12164a 
their teaching, they are persuaded to make sense of different aspects of teaching individually and collectively (Farrell, 2007; Koutselini, 2008). According to the findings of studies (Farrell, 1998, 2011, 2013, 2016; Lee, 2007; Yayli, 2009; Abednia et al., 2013; Min, 2013; Yigitoglu and Belcher, 2014; Soodmand-Afshar and Farahani, 2015; Faghihi and Anani-Sarab, 2016; Moradkhani et al., 2017), teachers need to be equipped with reflective strategies and reflection is considered to be an essential tool in teachers' professional development (Burton, 2009). Teachers should reflect on their teaching practices and act according to their reflection findings (Kumaravadivelu, 2006).

English language teachers are by no means an exception and they are also considered to be active decision makers in their teaching process rather than passive knowledge consumers (Borg, 2003). Reflective EFL teachers critically examine their teaching beliefs and practices to enhance their teaching quality (Borg, 2011). Different cognitive, social and emotional characteristics of teachers, which define the teaching abilities, have been investigated; therefore, there is a relatively good collection of features in EFL literature, which shows the relationships of these indicators with the teachers' teaching gratifications (Monshi-Toussi et al., 2011). In EFL contexts, for instance, emotional intelligence, self-efficacy and critical thinking abilities have been investigated and found to be important factors in effective teaching (Birjandi \& Bagherkazemi, 2010; Ghanizadeh \& Moafian, 2010; Ghanizadeh \& Moafian, 2011). By the same token, reflective practices might be a strong predictor of effective teaching.

In spite of the increase in studying the influence of cognitive, affective and social abilities in teacher's effective teaching, there are few studies which have examined the relationship between EFL teachers' teaching qualities and their metacognitive abilities (Monshi-Toussi et al., 2011). Due to the findings of studies (Ghanizadeh, 2011; MonshiToussi et al., 2011; Ghonsooli and Ghanizadeh, 2013; Royaei, Ghonsooly, \& Ghanizadeh, 2014, 2015), teachers' self-regulation is one of those abilities which is useful for teachers and need to be investigated more. According to Zimmerman (2000), self-regulation is the degree to which learners are motivationally, meta-cognitively, and behaviorally diligent in their own learning duties and in gaining their objectives. Selfregulation refers to "self-generated thoughts, feelings, and actions that are planned and cyclically adapted to attainment of personal goals" (Zimmerman, 2000, p.14). Selfregulation is a metacognitive ability, which is highly important in teachers' decision making in the new socio-cognitive paradigm.

However, most of what has been said on reflective practice and self-regulation is at theory level and just a few empirical researches have investigated the relationship between the two constructs (Akbari, 2007; Winchester \& Winchester, 2014). Besides, to the researchers' knowledge, in EFL contexts, the majority of studies have been conducted in universities or in private language institutes rather than in public high school contexts, which seems to be a yawning gap in the literature. Although some studies have investigated the influence of reflective practices and self-regulation on effective teaching in isolation, the relationship between these two constructs has scarcely been investigated in the school EFL contexts. The current study is an effort to investigate the relationship between EFL high school teachers' reflective practices, their 
teaching experiences and their self-regulation. The special significance of this study is examining the degree to which teachers' engagement in reflective practice can predict their self-regulation.

\section{REVIEW OF THE RELATED LITERATURE}

\section{Theoretical framework}

\section{Reflective practices}

In the past few decades, a large number of studies have been conducted on the reflective teaching practice inspired by the works of Dewey (1933) and Schon (1983). They contended that learning is due to the coalition of experience with reflection and of theory with practice. Dewey (1933) argued that reflection makes people critical and scientific thinkers. He defined reflection as the "active, persistent, and careful consideration of any belief or supposed form of knowledge in the light of the grounds that support it and further conclusions to which it tends" (p.9). Also, referring to Dewey's ideas, Schon introduced two terms in the 1980s: reflection-in-action and reflection-on-action. Reflection in action is real life action that teachers get involved in as they encounter problems when teaching. Reflection-on-action, however, happens after teaching and is teacher re-examination of the action that occurred in the class.

In addition to Schon's twofold framework of reflection, Farrell (2004) has recommended five routes to reflective teaching. First, he refers to technical rationality, which is the effective use of technical knowledge of teaching practice by novice teachers. Reflection-in-action and reflection-on-action which are the second and third types were discussed above. The fourth type of reflection is reflection-for-action which is proactive in nature and, through developing certain procedures, "teachers can prepare for the future by using knowledge from what happened during class and what they reflected on after class" (Farrell, 2004, p. 31). Finally, he refers to action research as an important part of reflective teaching. It could be defined as a tool by which teachers become researchers of their own profession; they can have autonomy and their own voice to reflect on their problematic issues (Farrell, 2004).

Also, in the early 1980s, Schon revived the concept of reflection. In his works, Schon introduced the notion of "practitioner-generated" problems which he referred to as practitioners' involvement in a process of problem-setting rather than problem-solving (Farrell, 2007). The emphasis on studying teachers' reflective practices is due to the fact that reflection, as Burton (2009) contends, has been a necessary skill in teachers' professional development.

\section{Self-regulation}

Zimmerman (2000) defined self-regulation as the degree to which learners are motivationally, meta-cognitively, and behaviorally active in their learning process and in achieving their goals. Self-regulation refers to "self-generated thoughts, feelings, and actions that are planned and cyclically adapted to attainment of personal goals" (Zimmerman, 2000, p.14). Self-regulation is a meta-cognitive ability which is highly important in teachers' decision makings in the new socio-cognitive paradigm. In the 
realm of education, self-regulation skills are associated with student's achievement and motivation (Zimmerman \& Schunk, 2001). The trends observed with self-regulation seem to be related to the teachers' realm. Since research has indicated students' use of self-regulatory behaviors to be critical for academic achievement, it is reasonable that the teachers' use of self-regulatory strategies would positively affect their practices.

Zimmerman's $(1989,2000)$ self-regulation model shows that self-regulatory processes have three cyclical phases: forethought, performance control, and self-reflection. The forethought phase consists of processes necessary for preparation for action such as goal setting, strategic planning, and self-motivation beliefs. Teachers in this phase set specific goals to achieve at the end of a lesson. Based on the goals and the nature of subject matter, student characteristics, and available resources, teachers choose appropriate instructional methods. These processes are affected by a set of motivational beliefs such as goal orientation, intrinsic interest, and self-efficacy. The performance control phase consists of processes that happen during an action. These processes are categorized as self-control or self-observation. Self-control processes help learners direct their attention to the task and optimize their effort. Self-observation includes monitoring one's own performance, considering the existing conditions and the outcomes of performance (Zimmerman, 2000). In addition, emotional control is essential to the self-control and self-observation processes: it includes concentration and effort in the face of distractions (Pintrich \& Schunk, 2002). Finally, the self-reflection phase includes self-judgment and self-reaction processes. Self-judgment refers to selfevaluation which is the comparing of self-monitored performance with a standard or goal. Self-reaction, on the other hand, refers to satisfaction or dissatisfaction and affect following a performance (Zimmerman, 2002).

Reflective practices and self-regulation in Iranian EFL context

The findings of the recent researchers on reflective practice in EFL contexts have shown the effectiveness of involvement in reflective teaching practices. Most of the studies investigating teacher reflective practices in EFL context are qualitative and a few are quantitative or mixed- methods in design. To begin with, Farrell (1998) investigated how teacher group discussions enhanced their reflective thinking. He studied three experienced EFL teachers in Korea, who were discussing and reflecting on their teaching practices. The results showed that they talked about their own personal beliefs of teaching and the issues they encountered in their teaching. The three teachers were reflective to some extent, but the degree of their reflection differed. Farrell (2011) also studied the effect of peer observation on teaching process from a qualitative perspective. The study revealed that the feedbacks provided during the post observation discussions helped teachers involve great numbers of their students in classroom activities. In addition, Farrell (2013) studied three experienced ESL teachers reflecting on their work in a reflection group with the help of a facilitator (the researcher) as a part of their professional development. The findings revealed that teaching experience did not show teacher expertise if they did not actively and consciously reflect on these experiences. Farrell (2016) examined the novice EFL teachers' engagements in group reflection. The findings indicated that the teachers gained a better understanding of the issues they faced during the first teaching year. 
In addition, Lee (2007) investigated the dialogue or response journals of student teachers. The results indicated that being engaged in dialogue journals increased critical thinking in student teachers in Hong Kong. Yayli (2009) examined the kinds of reflection in the reflection diaries written by Turkish pre-service EFL teachers. The results revealed that a positive attitude toward journal writing and using it in their future teaching had been developed in teachers. But the teachers were not able to write critical reflection in their journals. Min (2013) examined an EFL writing teacher's self-research of her own beliefs and activities about how to give written feedback. The results of the analysis of the journal and log entries indicated the principles underlining her beliefs and showed how these beliefs underwent a change gradually toward the end of the semester. Also, Abednia et al. (2013) studied six EFL teachers' opinions about keeping reflective diaries and the contributions and challenges they faced during the study. The teachers stated that reflective journals helped them get self-awareness about their beliefs and practices. Yigitoglu and Belcher (2014) investigated ESL writing teachers' beliefs in their own first and second language writings. The research tried to discover what associations might be between the teachers' beliefs about the second language writing teaching and their experiences in their first and second language writing. The findings revealed that the teachers' L1 and L2 writings and literacy learnings affected their L2 instructional activities. Moradkhani et al. (2017) examined the relationship between EFL teachers' reflective practices and their self-efficacy. In this mixed-methods research, they studied 102 Iranian EFL teachers teaching in private language institutes through a survey and interviews. The findings indicated that all reflection subscales, except critical reflection, had significant positive relationships with teachers' selfefficacy. As is evident in the review so far, the vast majority of studies have investigated these concepts at private language schools or institutes, which warrants this study further since the present study examines the same issue in public school settings.

Faghihi and Anani-Sarab (2016), in a mixed-methods study, investigated Iranian EFL teachers' perceptions of their own level of reflection and the way their perceptions were realized in practice. In the first phase of the study, $60 \mathrm{EFL}$ teachers teaching in private language institutes were studied through using the reflection questionnaire. In the second phase, the teaching practices of six teachers from among the surveyed teachers were observed. The results showed a low level of reflection and the teachers relied more on their own rationalities in teaching.

Finally, Soodmand-Afshar and Farahani (2015) examined the relationship between reflective teaching and reflective thinking of Iranian EFL teachers considering their gender and experience. The results of this quantitative research indicated that there was a significant positive correlation between reflective teaching and reflective thinking. In addition, there were significant differences between male and female and highexperienced and low-experienced Iranian EFL teachers in reflective teaching and thinking.

In EFL context, Ghanizadeh (2011) investigated the relationship between Iranian EFL teachers' self-regulation and their critical thinking abilities. The findings of this quantitative study indicated that there was a positive relationship between self-regulation 
and critical thinking. In addition, significant correlations were found between teachers' self-regulation, their teaching experience and their age. Ghonsooli and Ghanizadeh (2013), in a quantitative study, examined the relationship between EFL teachers' sense of self-efficacy and their self-regulation. The findings of the study indicated a significant relationship between teachers' self-regulation and self-efficacy beliefs. Also, there were significant relationships between teachers' self-regulation, their experience and age. But there was not significant relationship with gender. In addition, Monshi-Tousi et al. (2011) studied the relationship between EFL teachers' self-regulation and their teaching effectiveness. The findings of this quantitative study revealed that there was a significant relationship between EFL teachers' self-regulation and their teaching effectiveness. The relationship between the two constructs has received no attention in both mainstream and EFL teacher education literature. The present study is the first attempt demonstrating the relationship between EFL teachers' reflective practices and their selfregulation through a quantitative design. In addition, the mediating role of teachers' length of teaching experience on their self-regulation was examined. Also, as this literature review shows, no empirical study has opted to investigate the relationship between the two constructs in an EFL high school context based on a quantitative design. The main goal of this research is to empirically investigate the hypothesized relationship between reflective practices and self-regulation of EFL teachers. The study also examines the relationship between EFL teachers' experience and their selfregulation. In so doing and to fill this gap within the high school EFL context, the following research questions were examined in this study:

RQ1: Is there any significant correlation between EFL teachers' reflective practices, its subscales and their self-regulation?

RQ2: Do EFL teachers' reflective practices, their teaching experiences and the of interaction experience and reflective practices predict their self-regulation

\section{METHOD}

The participants of the current study were selected from among EFL teachers according to a convenience sampling method from different junior and senior high schools in Urmia and Nagadeh, two cities in West Azerbaijan province of Iran. There were more than 150 EFL teachers and 103 teachers accepted to participate and complete the two questionnaires. The participants consist of 56 females and 47 males. Their teaching experience ranged from 1 to 25 years, with the Mean score of 15.47 and the Median 15.00. After a short explanation as to the aims of the study, all teachers received the two questionnaires in hard copies, that is, the researcher saw them and handed the questionnaires to them in person. Then, they completed them at home and returned them later.

\section{Instrumentation}

The questionnaires included demographic data like: years of teaching, gender, and the level and field of academic studies.

English Language Teaching Reflection Inventory (ELTRI) 
The first questionnaire is the English Language Teaching Reflection Inventory (ELTRI) designed by Akbari et al. (2010). This questionnaire has 29 items in five subscales, which assess participants' reflective practices. The first subscale is practical reflection, which includes teachers' discussions of teaching issues with their peers, observing other teachers' classes or being observed by other teachers, and writing reflective diaries about their teaching activities. The second one is cognitive reflection including teachers' attending in conferences or reading professional journals. The third subscale is affective reflection, which includes teachers trying to understand their students' background and to know their ideas and expectations about different teaching activities. The fourth subscale is metacognitive reflection, which includes teachers' beliefs about the philosophy of teaching, critical assessing of their own teaching, and conceptions of their own previous teachers' teaching strategies. The last subscale is critical reflection related to teachers' knowledge of the social and political issues affecting the teaching process and the classroom context. This questionnaire is based on a 5-point Likert scale ranging from (1) "never" to (5) "always".

\section{Teacher Self-Regulation Scale (TSRS)}

The second questionnaire is the Teacher Self-Regulation Scale (TSRS), designed by Yesim, Sungur and Uzuntiryaki (2009). This questionnaire is based on Zimmerman's self-regulation theory. It has 41 items and uses a 6-point Likert scale varying from (1) "strongly disagree" to (6) "strongly agree". The first item is a filler item, which was not used in analysis. The total score on 40 items were calculated to get an overall indication of teachers' self-regulation. The total reliability of the scale, estimated by Cronbach's alpha, is 0.89 . The nine factors in the teacher self-regulation are: goal setting, which is determining aims to guide activities during teaching; intrinsic interest, which is beliefs related to interest in the teaching; performance goal orientation, which refers to the aims to act better than other teachers and to make others believe in one's own knowledge; mastery goal orientation, which is goals to develop abilities in teaching and master the teaching activity based on their own principles; self-instruction, which refers to the process of assessing one's own teaching and making changes in instruction if necessary; emotional control, which refers to skills to control feelings and emotions; selfevaluation, which refers to evaluating their teaching activities by comparing them with their own past activities; self-reaction relates to emotional responses to their own teaching activities, and the last one, help-seeking is about getting help from others to solve problems of their own teaching activities.

\section{Data Analysis}

A quantitative method was used for data collection and analysis. First, 150 questionnaires were given to the participants in the form of hard copies. 106 copies were returned and after eliminating three questionnaires which were incomplete or carelessly completed, 103 questionnaires remained. The data were then fed into SPSS statistical software. By employing Kolmogorov-Smirnov test, the normality of distribution was ensured. Next, the relationship between teachers' reflective practices and their selfregulation was examined by running Spearman correlation coefficient formula. In these sets of correlations, the relationships between participants' gained scores on the 
reflective inventory and its subscales and their scores on the self-regulation scale were examined. Additionally, the power of reflection subscales and the teachers' experiences in predicting EFL teachers' self-regulation were investigated by conducting a multiple regression analysis.

\section{FINDINGS}

Table (1) indicates the descriptive findings of the overall scores of teachers' reflective practices, its five subscales, teachers' experiences and the overall scores of their selfregulation in the present study.

Table 1

Descriptive results of teachers' reflection, its subscales, experience and self-regulation

\begin{tabular}{lllllc}
\hline & Minimum & Maximum & Mean & SD & KS Sig. \\
\hline Reflection & 57.00 & 121.00 & 94.11 & 14.09 & 0.200 \\
\hline Practical (sub 1) & 9.00 & 26.00 & 17.44 & 4.66 & 0.000 \\
\hline Cognitive (sub 2) & 8.00 & 29.00 & 17.89 & 4.38 & 0.008 \\
\hline Affective (sub 3) & 4.00 & 15.00 & 11.75 & 2.48 & 0.000 \\
\hline Meta-cognitive (sub 4) & 16.00 & 34.00 & 26.88 & 4.99 & 0.000 \\
\hline Critical (sub 5) & 10.00 & 30.00 & 19.97 & 4.86 & 0.003 \\
\hline Self-regulation & 117.00 & 299.00 & 192.13 & 30.18 & 0.000 \\
\hline Experience & 1.00 & 25.00 & 15.47 & 5.12 & 0.019 \\
\hline
\end{tabular}

According to table 1, the distribution of scores is not always normal $(\operatorname{sig}<0.05)$ for some of the variables; therefore, the researchers decided to run non-parametric tests. In so doing, instead of Pearson correlation, Spearman correlation coefficient was computed.

Phase One (RQ1): The correlations between EFL teachers' reflective practices, its five subscales, their experiences and self-regulation

Table 2

Correlation between total reflection, its subscales, experience and total self-regulation

\begin{tabular}{lllllllr}
\hline & Reflection & sub1 & sub2 & sub3 & sub4 & sub5 & Experience \\
\hline Self-regulation & $0.746^{* *}$ & $0.356^{* *}$ & $0.807^{* *}$ & $0.349^{* *}$ & $0.744^{* *}$ & $0.199^{*}$ & $0.292^{* *}$ \\
\hline Sig. & 0.000 & 0.000 & 0.000 & 0.000 & 0.000 & 0.044 & 0.003 \\
\hline **Two tailed, significant at 0.01 & & & & & & \\
*Two tailed, significant at 0.05 & & & & & &
\end{tabular}

According to table 2 , there is a positive significant relationship between reflective practice and self-regulation $(r=0.74 ;$ sig<0.05). The relationship between experience and self-regulation is also significantly positive $(r=0.29$; $\operatorname{sig}<0.05)$. The relationship between the subscales of reflective practice and self-regulation is also significantly positive $(\mathrm{sig}<0.05)$. Therefore, the first and second research hypotheses " $\mathrm{RH} 0_{1}$ : There is not a significant relationship between EFL teachers' reflective practices and their selfregulation., and $\mathrm{RHO}_{2}$ : there is not a significant relationship between the subscales of EFL teachers' reflective practices and their self-regulation." are rejected. 
Phase Two (RQ2): The results of multiple regression analysis for teachers' reflection, experience and self-regulation

In this phase of the analysis of the data, a multiple regression is run in order to find out the predictive power of reflective practices as the independent (explanatory) variable and experience as the moderator of the relationship between reflective practices and self-regulation as the response (dependent) variable.

Table 3

The results of regression analysis for teachers' reflection, experience and self-regulation Model Unstandardized coefficients Standardized coefficient $\quad$ Significance of the slope

\begin{tabular}{lccccccc} 
& $\mathrm{B}$ & Std. error & & Beta & & & \\
& Reflection & 1.412 & 0.160 & & 0.659 & & Sig. \\
\hline Experience & 0.864 & 0.451 & & 0.146 & & 8.806 & 0.000 \\
\hline Interaction* & 0.001 & 0.033 & & 0.022 & 1.915 & 0.058 \\
\hline
\end{tabular}

*The interaction between reflective practices and experience

Dependent variable: Total self-regulation

Unstandardized coefficients show how much our response variable varies with an explanatory variable while all other explanatory variables are held constant. As is clear from table 3, the unstandardized coefficient for model one (reflection) is (1.41, sig<0.05) and for model two (experience) $(0.86, \mathrm{p}>0.05)$. The unstandardized coefficient for the third model (the interaction between experience and reflective practices) is $(0.001, \mathrm{p}>0.05)$, which shows that when other variables are held constant, only the first model, that is the reflective practices, can predict the response variable or account for the variation in the response variable (self-regulation).

Table 4

The model summary for teachers' reflection, experience and self-regulation

\begin{tabular}{|c|c|c|c|c|c|c|c|}
\hline \multirow[t]{2}{*}{ Model } & \multirow[t]{2}{*}{$\mathrm{R}^{2}$} & \multirow{2}{*}{$\begin{array}{c}\text { Adjusted } \\
\mathrm{R}^{2}\end{array}$} & \multirow{2}{*}{$\begin{array}{l}\text { Std. } \\
\text { error } \\
\text { of } \\
\text { the } \\
\text { stimate }\end{array}$} & \multicolumn{4}{|c|}{ Change Statistics } \\
\hline & & & & $\begin{array}{l}\mathrm{R}^{2} \\
\text { Change }\end{array}$ & $\begin{array}{c}\mathrm{F} \\
\text { Change }\end{array}$ & df 1 df 2 & $\begin{array}{l}\text { Sig. F } \\
\text { Change }\end{array}$ \\
\hline Reflection $0.659 \mathrm{a}$ & 0.434 & 0.429 & 22.81 & 0.434 & 77.54 & 101 & 0.000 \\
\hline Experience $0.674 b$ & 0.454 & 0.443 & 22.51 & 0.020 & 3.67 & 100 & 0.058 \\
\hline Interaction $0.674 \mathrm{c}$ & 0.454 & 0.438 & 22.63 & 0.000 & 0.001 & 99 & 0.972 \\
\hline
\end{tabular}

As table 4 shows, the first model $\left(\mathrm{R}^{2}=-0.43\right.$; $\left.\operatorname{sig}<0.05\right)$ is a good predictor of the response variable (self-regulation). And the second model $\left(\mathrm{R}^{2}=-0.45 ; \mathrm{sig}>0.05\right)$ is not a good predictor of the response variable. The first model can account for 0.43 percent of the variation in the response variable and the second model can do this for 0.02 . However, the third model $\left(\mathrm{R}^{2}=0.45\right.$; sig $\left.>0.05\right)$ is not a predictor of self-regulation and it can account for 0.00 of the variation in the predicted variable. In other words, the first 
model, that is reflective practice, can predict self-regulation among teachers and the second and third models, that is experience and the interaction between experience and reflective practices, cannot predict self-regulation.

Therefore, the hypothesis "RH03: Experience does not moderate the relationship between EFL teachers' reflective practices and their self-regulation." is supported. Hypothesis "RH04: EFL teachers' reflective practices do not predict their selfregulation" is rejected and "RH05: EFL teachers' experience does not predict their selfregulation" is supported; "RH06: The interaction of experience and reflective practices of EFL teachers does not predict their self-regulation" is supported as well.

\section{DISCUSSION}

The present study investigated the association between Iranian high school EFL teachers' reflective practices, their self-regulation and their teaching experiences through their self-report questionnaires. The analysis of the data showed that there was a positive relationship between the participant teachers' reflective practices and their selfregulation. In other words, teachers who had higher levels of reflective practices were more self-regulated in their teachings. However, there was no significant relationship between the teachers' self-regulation and their teaching experiences, which is an unexpected finding and the main focus of our discussion in the present study. As the analysis of the self-report data showed, the participant teachers in this study improved self-regulation regardless of their teaching experiences. This may be an indication that all the teachers were aware of the positive contributions of being reflective and selfregulated in their practices. This shows that there is a need for reflection and selfregulation training programs and opportunities for pedagogical content knowledge development for all the teachers regardless of their teaching experiences in the context of this study - public high schools.

The findings of the present study are in line with the theoretical proposals for the relationship between reflective practices and self-regulation as two distinct constructs and successful teaching proposed by scholars. This backs the reasoning that the development of the skills of reflection supports the self-monitoring strategy of selfregulation (Pintrich, 2000). This suggests that the more the teachers engage in reflection, the more they will possess self-regulation strategies. Randi (2004) assumed that effective teachers are self-regulated persons who make their beliefs active by taking proper actions which lead to effective teaching. Also, according to Delfino, Dettori, and Persico (2010), teaching as a complicated profession needs self-regulated teachers who can teach effectively. In line with this, Dembo (2001) assumed that for effective teaching, teachers not only need content knowledge, but also should have self-regulation abilities.

However, there was no significant relationship between the teachers' self-regulation and their teaching experience. Therefore, without regarding their teaching experience and, based on their self-report, the teachers in this study improved the self-regulation skills and their decision-makings (Zeidner, Boekaerts \& Pintrich, 2000). This finding is not in 
line with the assumption that teachers' self-regulation develops with every year of teaching experience (Zimmerman, 2000).

Also, in the EFL context, the findings of the present study are in accordance with some and in conflict with some other empirical studies. However, there were differences between high-experienced and low-experienced Iranian EFL teachers in reflective teaching and thinking which is not in line with the findings of the current study. Ghonsooli and Ghanizadeh (2013), in a quantitative study, examined the relationship between EFL teachers' sense of self-efficacy and their self-regulation. The findings of the study indicated a significant relationship between teachers' self-regulation and selfefficacy beliefs. Also, significant correlations were found between teachers' selfregulation and their teaching experience which also does not support the findings of the present study.

In a nutshell, both in private language institutes and in public high schools, all teachers are in an urgent need of programs for reflection and self-regulation training by skillful teacher educators. The curriculum is often imposed on teachers; before beginning their teaching career, they are provided with a very short teacher training course whose aim is to give them directions for classroom instruction followed by classroom observation inspecting them to make sure they are sticking to the directions.

\section{CONCLUSION}

The findings of the present research showed that Iranian EFL teachers who have high levels of reflective practice are self-regulated teachers in their teaching. Self-regulatory skills and strategies also lead to effective teaching of teachers through determining aims to guide activities during teaching, self-awareness of interest in the teaching, setting goals to develop abilities in teaching and master the teaching activity based on their own principles, assessing one's own teaching and making changes in instruction if necessary, controlling feelings and emotions, evaluating their teaching activities by comparing them with their own past activities, emotional responses to their own teaching activities, and finally getting help from others to solve problems of their own teaching activities. These strategies and skills encourage teachers to be successful and motivated to do their best in their profession. Therefore, teacher trainers, educational organizations, policy makers, curriculum designers, academic specialists, administrators, course developers and researchers can introduce these strategies to teachers through training courses and programs so that teachers equip themselves with these skills. Also, self-regulated teachers can teach these skills and strategies to their learners to improve their learning.

The EFL trainers and teachers themselves should take into account the positive effects of reflective practices and self-regulation on teaching effectiveness. Therefore, teacher educators should add reflective practices and self-regulation courses to the teacher training programs. In addition, it is important for teachers to have activities related with reflective practices and self-regulation learning.

EFL teaching and teacher training programs are recommended to improve EFL teachers' reflective practices, the curriculum should give more freedom to teachers' decision making at all levels including curriculum change, selection of teaching materials and 
classroom procedures. They are also recommended to provide an environment supportive of reflection. The traditional didactic inspection of teachers' classroom instruction should change to a negotiable one in which teachers will be supported in their efforts to develop professionally. Teachers should also be encouraged to establish communities of practice to engage in a process of collective learning using collaborative activities. Teacher trainers can introduce reflective practices and self-regulatory strategies to teachers through training courses and workshops so that teachers equip themselves with these skills. Reflective practices like group discussion, peer observation, reflective diary writing, attending in conferences or reading professional journals, trying to understand their students' background and to know their ideas and expectations about different teaching activities, teachers' beliefs about the philosophy of teaching, critical assessing of their own teaching, conceptions of their own previous teachers' teaching strategies, and teachers' knowledge of the social and political issues affecting the teaching process and the classroom context. And self-regulatory strategies like determining aims to guide activities during teaching, self-awareness of interest in the teaching, etc. as mentioned above.

\section{REFERENCES}

Abednia, A., Hovassapian, A., Teimournezhad, S., \& Ghanbari, N. (2013). Reflective journal writing: Exploring in-service EFL teachers' perceptions. System, 41, 503-514.

Akbari, R. (2007). Reflections on reflection: A critical appraisal of reflective practices in L2 teacher education. System, 35, 192-207.

Akbari, R., Behzadpoor, F., \& Dadvand, B. (2010). Development of English Language teaching reflection inventory. System, 38, 211-227.

Birjandi, P., \& Bagherkazemi, M. (2010). The relationship between Iranian EFL teachers' critical thinking ability and their professional success. English Language Teaching, 3 (2), 135-145.

Borg, S. (2003). Teacher cognition in language teaching: A review of research on what teachers think, know,believe, and do. Language Teaching, 36, 81-109.

Borg, S. (2011). Language teacher education. J. Simpson, the Routledge handbook of applied linguistics. New York: Routledge.

Burton, J. (2009). Reflective practice. In A. Burns \& J. C. Richards (Eds), The Cambridge Guide to Second Language Teacher Education (298-307). Cambridge: Cambridge University Press.

Delfino M., Dettori G. \& Persico D. (2010). An online course fostering self-regulation of trainee teachers. Psicothema, 22 (2), 299-305.

Dembo M. H. (2001). Learning to teach is not enough- Future teachers also need to learn how to learn. Teacher Education Quarterly, 28, 23-35.

Dewey, J. (1933). How We Think. Boston: D. C. Heath and Co Publishers. 
Faghihi, G., \& Anani-Sarab, M. R. (2016). Teachers as reflective practitioners: A survey on Iranian English teachers' reflective practices. The Journal of Teaching Language Skills, 7(4), 57-86.

Farrell, T. S. C. (1998). Reflective Practice in an EFL Teacher Development Group. Paper presented at the $32^{\text {nd }}$ TESOL Conference 1998, Seattle, USA.

Farrell, T.S.C., 2004. Reflective Practice in Action: 80 Reflection Breaks for Busy Teachers. Corwin Press (Sage Publications), Thousand Oaks, CA (USA).

Farrell, T.S.C. (2007). Reflective practice for language teachers: from research to practice. London: Continuum Press.

Farrell, T. S. C. (2011). 'Keeping SCORE': Reflective practice through classroom observations. RELC Journal, 42, 265-27.

Farrell, T. S. C. (2013). Reflecting on ESL teacher expertise: A case study. System, 41, 1070-1082.

Farrell, T. S. C. (2016). Surviving the transition shock in the first year of teaching through reflective practice. System, 61, 12-19.

Ghanizadeh, A. (2011). An investigation into the relationship between self-regulation and critical thinking among Iranian EFL teachers. The Journal of Technology of Education, 5 (3), 213-221.

Ghanizadeh, A., \& Moafian, F. (2010). The role of EFL teachers' emotional intelligence in their success. ELT Journal, 64 (4), 424-435.

Ghanizadeh, A., \& Moafian, F. (2011). The relationship between Iranian EFL teachers' sense of self-efficacy and their pedagogical success in Language Institutes. Asian EFL Journal, 13 (2), 249-272.

Ghonsooly, B., \& Ghanizadeh, A. (2013). Self-efficacy and self-regulation and their relationship: A study of Iranian EFL teachers. The Language Learning Journal, 41(1), 68-84.

Koutselini, M., (2008). Participatory teacher development at schools: processes and issues. Action Res. 6 (1), 29-48.

Kumaravadivelu, B. (2006). Understanding language teaching: From method to postmethod. New Jersey:Lawrence Erlbaum Associates, Inc.

Lee, I. (2007). Preparing pre-service English teachers for reflective practice. ELT Journal, 61, 321-329.

Min, H. T. (2013). A case study of an EFL writing teacher's belief and practice about written feedback. System, 41, 625-638.

Monshi Toussi, M. T., Boori, A. A., \& Ghanizadeh, A. (2011). The role of EFL teachers' self-regulation in effective teaching. World Journal of Education, 1(2), 39-48. 
Moradkhani, S., Raygan, A., \& Mohammad Sadegh Moein, M.S. (2017). Iranian EFL teachers' reflective practices and self-efficacy: Exploring possible relationships. System, $65,1-14$.

Pintrich, P. R. (2000). The role of goal orientation in self-regulated learning. In M. Boekaerts, P.R. Pintrich \& M. Zeidner, (Eds.), Handbook of self-regulation (pp. 451502). San Diego, CA, Academic Press.

Pintrich, P.R., \& Schunk, D.H. (2002). Motivation in education: Theory, research, and Applications (2nd ed.). Columbus, OH: Merrill-Prentice Hall.

Schön, D. (1983). The reflective practitioner: How professionals think in action. NewYork, NY: Basic Books.

Randi J. (2004). Teachers as self-regulated learners. Teachers' college record, 106, (9), 1825-1853.

Royaei, N., Ghonsooly, B., \& Ghanizadeh, A. (2014). Narrative Intelligence and EFL Teachers' self-regulation. Foreign Language Teaching, 2 (6), 14-20.

Royaei, N., Ghonsooly, B., \& Ghanizadeh, A. (2015). A mixed methods analysis of EFL teachers' self-regulated strategies and burnout. International Journal of Research Studies in Psychology, 4 (2). 71-81.

Soodmand-Afshar, H. \& Farahani, M. (2015). Reflective Thinking and Reflective Teaching among Iranian EFL Teachers: Do Gender and Teaching Experience Make a Difference? Paper presented at $2^{\text {nd }}$ Global Conference on Linguistics and Foreign Language Teaching, LINELT-2014, Dubai-United Arab Emirates, 11-13, 2014.

Winchester, T. M., \& Winchester, M. K. (2014). A longitudinal investigation of the impact of faculty reflective practices on students' evaluations of teaching. British Journal of Educational Technology, 45, 112-124.

Yayli, D. (2009). Reflective practices of preservice teachers in a listening skill course in an ELT department. Paper presented at World Conference on Educational Sciences 2009.

Yesim, C.A., Sungur, S., \& Uzuntiryaki, E. (2009). Teacher self-regulation: examining a multidimensional construct. Educational Psychology 29(3), 345-356.

Yigitouglu, N., \& Belcher, D. (2014). Exploring L2 writing teacher cognition from an experiential perspective: The role learning to write may play in professional beliefs and practices. System, 47, 116-124.

Zeidner M., Boekaerts M. \& Pintrich P. R.(2000). Self-regulation: Directions and challenges for future research. In M. Boekaerts, P.R. Pintrich \& M. Zeidner (Eds.), handbook of self-regulation (pp. 749-768). San Diego: Academic Press.

Zimmerman, B. J. (1989). A social cognitive view of self-regulated academic learning. Journal of Educational Psychology, 81, 329-339. 
Zimmerman, B.J. (2000). Attaining self-regulation: a social cognitive perspective. In M. Boekaerts, P.R. Pintrich \& M. Zeidner, Handbook of Self-Regulation (pp.13-39). San Diego, CA: Academic Press.

Zimmerman, B.J. (2002). Becoming a self-regulated learner: An overview. Theory into Practice, 41, 64-70.

Zimmerman, B.J. \& Schunk D. (2001). Reflections on theories of self-regulated learning and academic achievement. In B. Zimmerman \& D. Schunk (Eds.), Self-Regulated Learning and Academic Achievement: Theoretical Perspectives (2nd Ed.) (pp. 289307). Mahwah, NJ: Erlbaum.

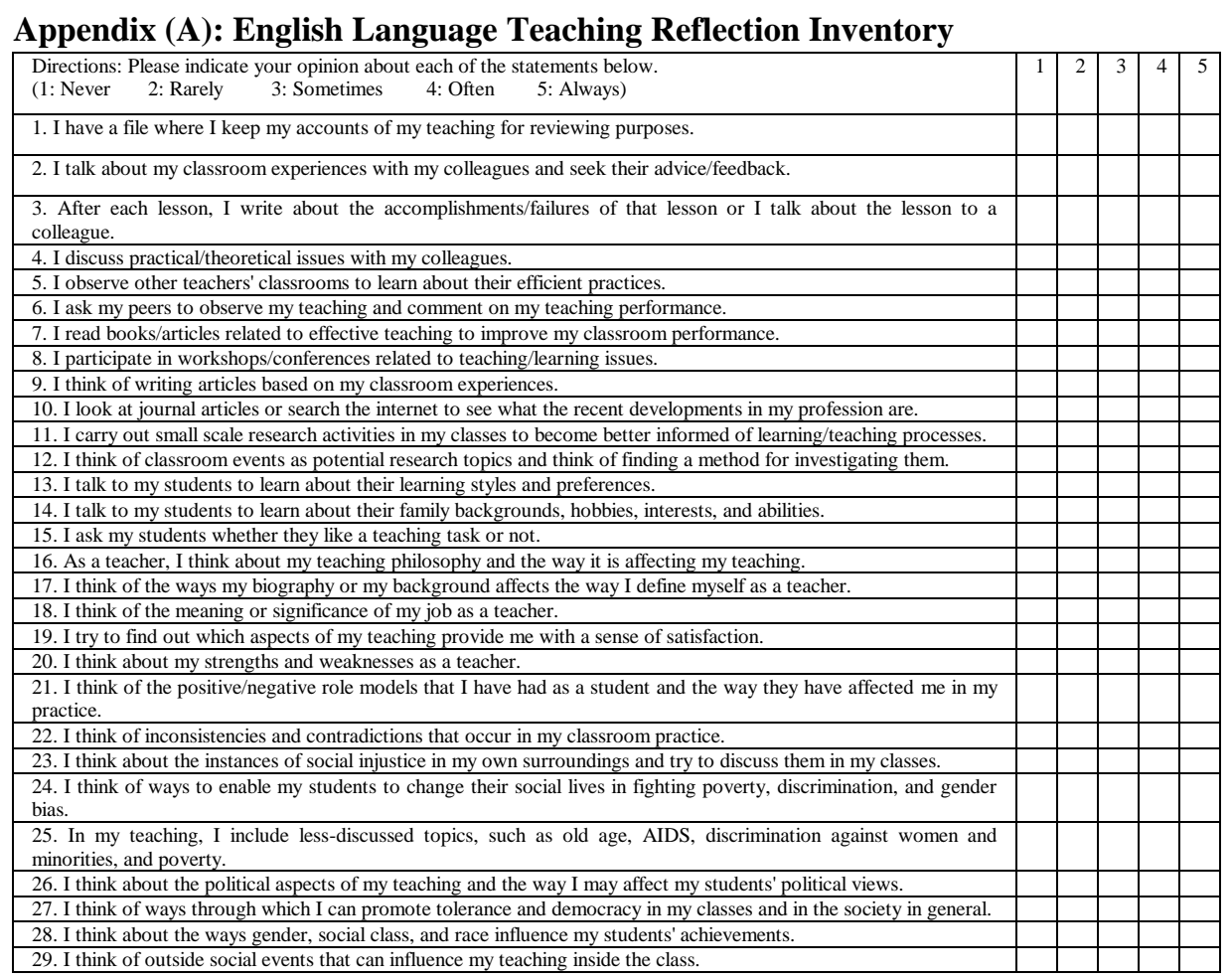




\section{Appendix (B): Teacher Self-Regulation Scal}

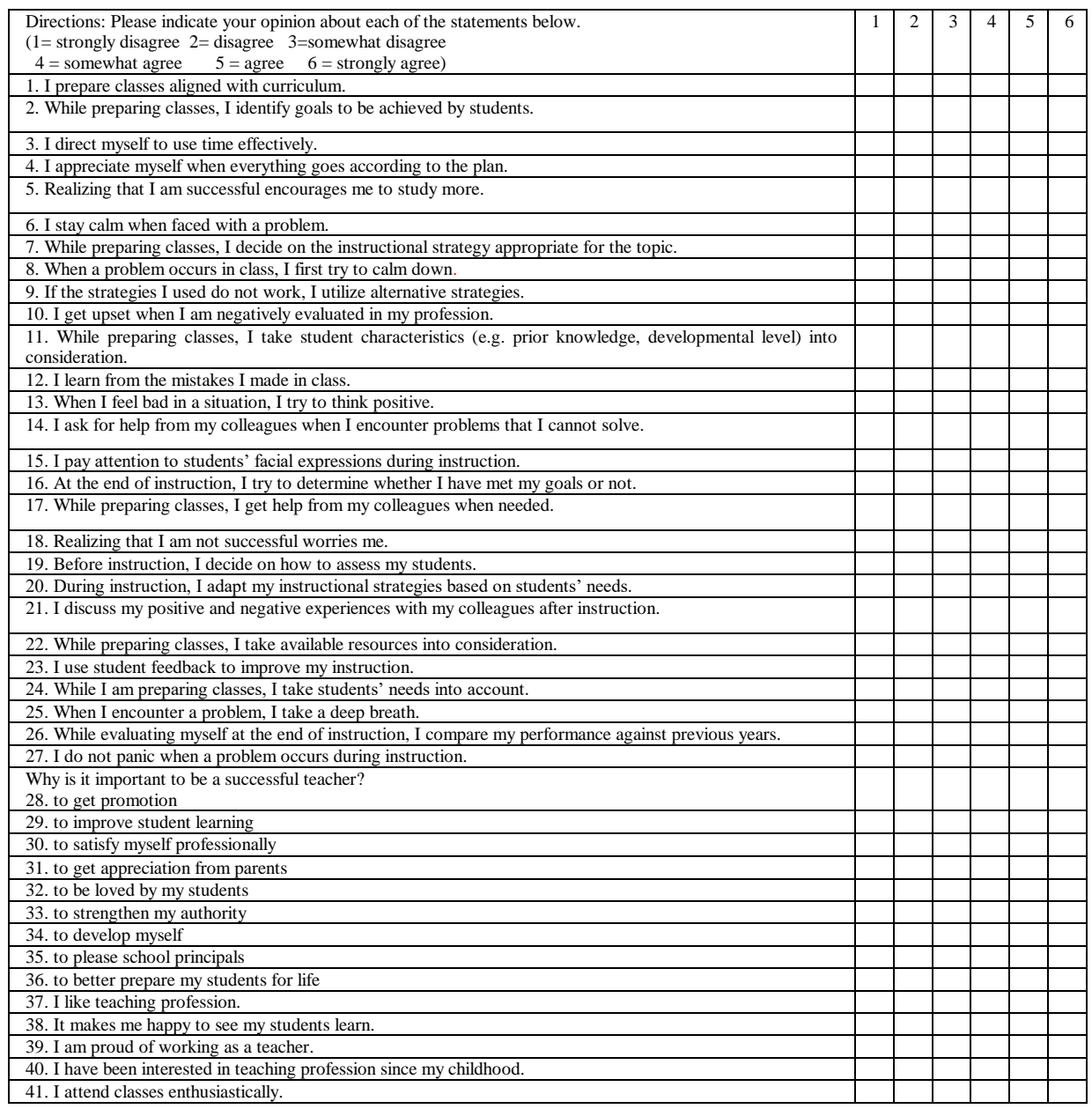

International Journal of Instruction, January $2019 \bullet$ Vol.12, No.1 